\title{
Engineering Geological Investigations of a Nuclear Building Foundation - A Case Study from Atomic Power Project, India
}

\author{
A.K. Naithani ${ }^{*}$, J.K. Jain ${ }^{2}$, Prasnna Jain ${ }^{1}$, L.G. Singh ${ }^{1}$ and Rabi Bhusan ${ }^{1}$ \\ ${ }^{1}$ Scientist, National Institute of Rock Mechanics, Bengaluru - 560 070, India \\ ${ }^{2}$ Additional Chief Engineer, Nuclear Power Corporation of India Ltd., Rajasthan, India \\ Email: ajay_naithani@hotmail.com
}

\begin{abstract}
Engineering geological foundation investigations are essential for important civil structures to provide permanent data set for geological interpretations. At Rawatbhata, India, two units of 700 MW each Pressurized Heavy Water Reactor (PHWR) type Nuclear Reactors are being constructed adjacent to existing Rajasthan Atomic Power Project (RAPP) units 1 to 6. Engineering geological mapping on 1:100 scale was carried out for Nuclear Building- 8 structures to evaluate the design basis foundation parameters. $1 \mathrm{~m} \mathrm{x} 1 \mathrm{~m}$ grids were prepared for mapping of the floors and walls. Based on the field observations and evidences, it was found that the floor area consists of fine to medium grained, compact quartzitic sandstones. The floor region was seen to contain certain iron stained and fractured zone. No evidence of faulting was observed on the surface of the floor areas. However, there were some isolated patches of soft, weathered/altered rock and small fractures in the rocks. The intact rock properties at the foundation levels were evaluated considering the necessity in the overall context of the design requirements of the foundations. Geotechnical assessment of the foundations of RB-8, RAB- 8 and ECCS north and south pits was done on the basis of detailed engineering geological mapping, geological drill holes logging data, rock mass permeability values, geophysical profiling and laboratory test results. Based on investigations recommendations for the treatment of foundations were given. Consolidation grouting up to $9 \mathrm{~m}$ depth in the foundation using primary at $6 \mathrm{~m}$ spacing and secondary holes at $3 \mathrm{~m}$ spacing was recommended. After detailed investigations it was found that, the foundation is suitable to locate a nuclear power plant.
\end{abstract}

Keywords: Nuclear building, engineering geology, raft foundation, discontinuity, sandstone

\section{Introduction}

The under construction Rajasthan Atomic Power Project (RAPP) consists of two units $7 \& 8$ of $700 \mathrm{MW}$ each Pressurised Heavy Water Reactor (PHWR) type Nuclear Reactors, adjacent to the existing RAPP1 to 6 units, which are under operation. In the plan layout, RB $7 \& 8$ are located at 108 meter center to center. The PHWR reactor design has been developed since 1950s in Canada as the CANDU and more recently also in India. It uses natural uranium $(0.7 \%$ U-235) oxide as fuel, hence needs a more efficient moderator, in this case heavy water $\left(\mathrm{D}_{2} \mathrm{O}\right)$. RAPP-7 \& 8 site is located on the right bank of Chambal River at Rawatbhata in Chittorgarh District of Rajasthan. The site is situated about $64 \mathrm{~km}$ from Kota. The site is on a gently sloping terrain and rocks are available within few centimeters from the surface [1].

In order to evaluate the design basis foundation parameters engineering geological mapping on 1:100 scale was carried out for the Nuclear Building-8 (NB-8) structures. Nuclear Building-8 structures include Emergency Core Cooling System (ECCS) north and south pits, Reactor Building (RB-8) and Reactor Auxiliary Building (RAB-8), resting on different base raft (Fig. 1). The NB is founded on a common raft having top elevation at RL. $90.00 \mathrm{~m}$ in general except for RB portion, where top elevation is at RL. $91.70 \mathrm{~m}$. All the discontinuities in the rock mass of NB-8 with the zone of influence of the foundation and walls were identified and mapped. The primary purpose of the mapping was to provide a permanent record of conditions during the excavation. Mapping was done to assess the requirement of any ground improvement by adopting suitable engineering measures. Core samples were tested for physicomechanical properties of rocks in the Laboratory. This permanent foundation record will assist in making better interpretation of post-construction foundation instrumentation data [2]. 


\section{Methodology}

Grids were prepared for mapping and the size of the grid was $1 \mathrm{~m}$ x $1 \mathrm{~m}$, which was decided based on the mapping accuracy and resolution required for such investigations. The vertical and horizontal scale of one grid of construction drawing was $20 \mathrm{~m}$ and as the area was mapped in 1:100 scale, the mapping grids $(1 \times 1 \mathrm{~m})$ were marked within one construction grid e.g. $18,18+1,18+2 \ldots . .18+19,19$ for northing and $\mathrm{w}, \mathrm{w}+1, \mathrm{w}+2 \ldots \mathrm{w}+19, \mathrm{x}$ for easting. Basic nomenclature for northing and easting was adopted from 'constructing drawing'. The difference between construction north and true north is $13^{\circ} 19^{\prime} 27^{\prime}$. All the lithological and structural features were observed and mapped using Total Station surveying equipment. Detailed examination of rock types in each grid was carried out which includes mineralogical composition, texture, classification and nomenclature and degree/grade of weathering. Fracture filling that have taken place in the study site were examined and recorded. The attitude and structure of the rocks, fractures and joint pattern present in the floor and walls were determined for mapping. ISRM [3] classification for weathered mass was used to characterize the rock mass into different grades (Table 1). The assessment of Rock Mass Rating [4] for sandstone rock masses was done based on the rock joints and their nature, drill cores and laboratory test data.

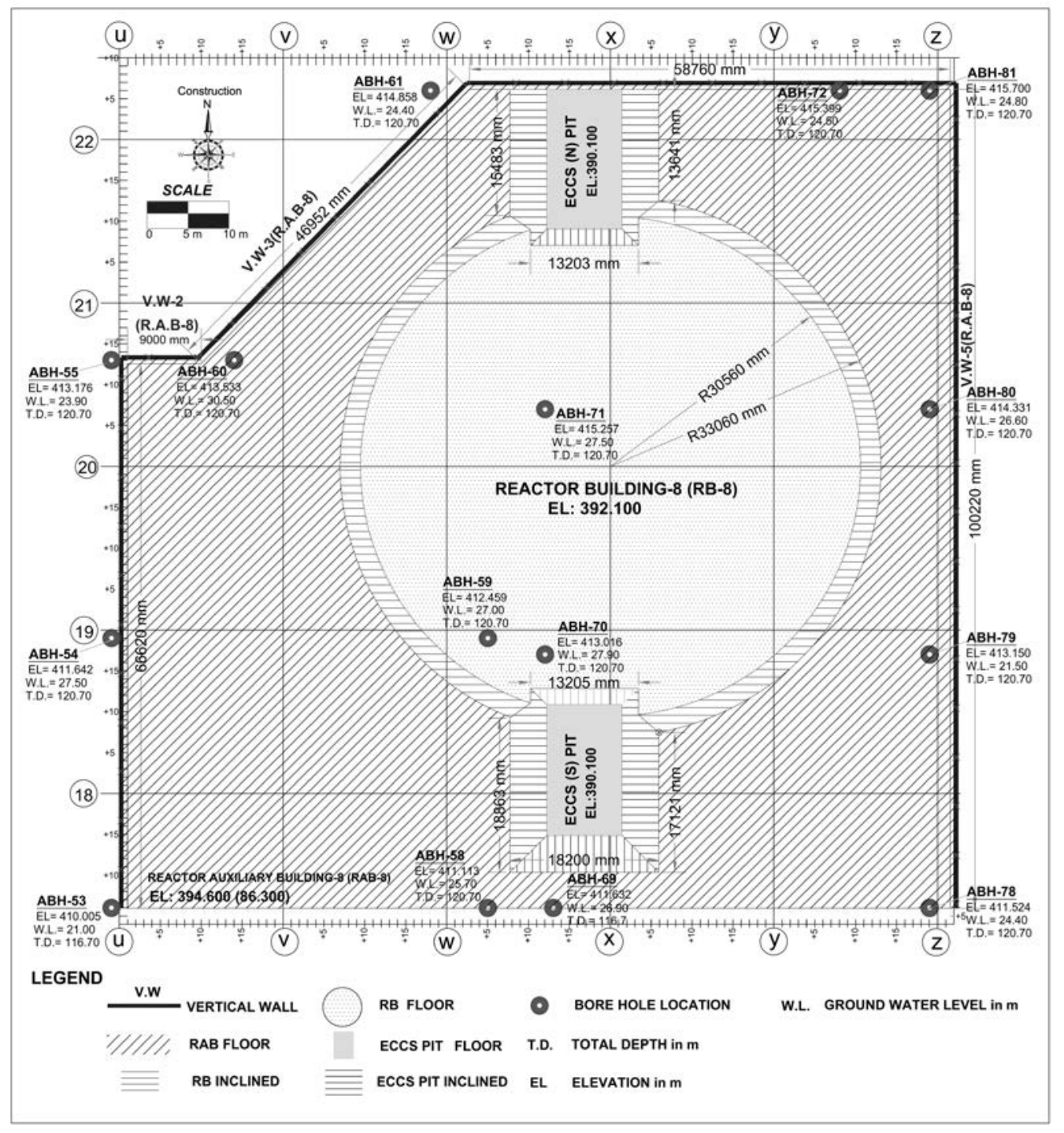

Figure 1. Plan map of nuclear building- 8 of RAPP unit 8 
Table 1. Description of weathering grade [3]

\begin{tabular}{|c|c|c|}
\hline Term & Description & Grade \\
\hline Fresh & $\begin{array}{l}\text { No visible sign of rock material weathering; perhaps slight discolouration on major } \\
\text { discontinuity surfaces. }\end{array}$ & I \\
\hline $\begin{array}{l}\text { Slightly } \\
\text { weathered }\end{array}$ & $\begin{array}{l}\text { Discolouration indicates weathering of rock material on discontinuity surfaces. All the } \\
\text { rock material may be discoloured by weathering and may be somewhat weaker } \\
\text { externally than in its fresh condition. }\end{array}$ & II \\
\hline $\begin{array}{l}\text { Moderately } \\
\text { weathered }\end{array}$ & $\begin{array}{l}\text { Less than half of the rock material is decomposed and/or disintegrated to a soil. Fresh } \\
\text { or discoloured rock is present either as a continuous framework or as corestones. }\end{array}$ & III \\
\hline $\begin{array}{l}\text { Highly } \\
\text { weathered }\end{array}$ & $\begin{array}{l}\text { More than half of the rock material is decomposed and/or disintegrated to a soil. Fresh } \\
\text { or discoloured rock is present either as a discontinuous framework or as corestones. }\end{array}$ & IV \\
\hline $\begin{array}{l}\text { Completely } \\
\text { weathered }\end{array}$ & $\begin{array}{l}\text { All rock material is decomposed and/or disintegrated to soil. The original mass } \\
\text { structure of the rock mass is still largely intact. }\end{array}$ & $\mathrm{V}$ \\
\hline Residual soil & $\begin{array}{l}\text { All rock material is converted to soil. The mass structure and material fabric are } \\
\text { destroyed. There is a large change in volume, but the soil has not been significantly } \\
\text { transported. }\end{array}$ & VI \\
\hline
\end{tabular}

\section{$3 \quad$ Geology of Project Area}

The project area is occupied by very hard and competent, fine to medium grained sandstone of Kaimur group of upper Vindhyan Super Group of Proterozoic age (940 \pm 40 million years) [5]. Stratigraphically within the $5 \mathrm{~km}$ radius area of RAPP-7 \& 8, a thick sequence of reddish shale is overlain by buff to reddish brown sandstone which is trending in NW-SE direction and dipping at $4^{\circ}$ to $5^{\circ}$ towards SW [6]. At a few places Vindhyan sandstone is directly overlain by soil consisting of silt and sand. Usually, beds are horizontal to sub-horizontal and general slope of the area is towards west i.e. towards Ranapratap Sagar reservoir. The prevalence of ripple marks in the strata is indicative of shallow water origin; while the red sandstones of the Kaimur indicate semi-arid and continental conditions. The Vindhyan super group is least metamorphosed and except in the lower part it does not show much effect of tectonism [7].

In the area fine to medium grained compact quartzitic sandstones are exposed after excavation. Drill holes data (ABH-53, ABH-54, ABH-55, ABH-58, ABH-59, ABH-60, ABH-61, ABH-69, ABH-70, ABH-71, $\mathrm{ABH}-72, \mathrm{ABH}-78, \mathrm{ABH}-79, \mathrm{ABH}-80$ and $\mathrm{ABH}-81$ ) confirmed that NB-8 area is covered by thin soil cover (up to $0.5 \mathrm{~m}$ ). In general from EL $408 \mathrm{~m}$ to EL $397 \mathrm{~m}$, fine to medium grained grayish-white quartzitic sandstones and from EL $397 \mathrm{~m}$ to EL $340 \mathrm{~m}$, fine to medium, fresh, thinly to thickly bedded purplish-gray quartzitic sandstones with layers of glauconite (up to $1 \mathrm{~cm}$ ) were recorded during the field mapping and logging of drill hole CBH-4, which was drilled from EL. $390.10 \mathrm{~m}$ in ECCS north pit location of NB-8. The rocks exposed below the foundation levels of RAB-8, RB-8 and ECCS pits, their thickness and RQD recorded during the field mapping and logging of bore holes CBH- 4 is given in Table 2 .

Table 2. Details of rock types recorded below the foundation levels of NB-8

\begin{tabular}{|c|c|c|c|c|c|c|}
\hline \multirow[t]{2}{*}{ Structures } & \multirow{2}{*}{$\begin{array}{l}\text { Foundation } \\
\text { Level }\end{array}$} & \multirow{2}{*}{$\begin{array}{l}\text { Rock Types at \& } 10 \mathrm{~m} \\
\text { below the foundation } \\
\text { level }\end{array}$} & \multicolumn{3}{|c|}{ Thickness of Beds $(\mathrm{cm})$} & \multirow{2}{*}{$\begin{array}{l}\text { Average } \\
\text { RQD }\end{array}$} \\
\hline & & & Minimum & Maximum & Average & \\
\hline \multirow[t]{2}{*}{ RAB-8 } & 394.600 & $\begin{array}{l}\text { Purplish-gray quartzitic } \\
\text { sandstone }\end{array}$ & 4.5 & 57.0 & 15.0 & 85.0 \\
\hline & & $\begin{array}{l}\text { Grayish-white quartzitic } \\
\text { sandstone }\end{array}$ & 16.0 & 65.0 & 39.0 & 100.0 \\
\hline RB-8 & 392.100 & $\begin{array}{l}\text { Purplish-gray quartzitic } \\
\text { sandstone }\end{array}$ & 4.0 & 94.0 & 33.0 & 86.0 \\
\hline $\begin{array}{l}\text { ECCS-N } \\
\text { Pits }\end{array}$ & 390.100 & $\begin{array}{l}\text { Purplish-gray quartzitic } \\
\text { sandstone }\end{array}$ & 1.0 & 67.0 & 19.0 & 89.5 \\
\hline
\end{tabular}


In the excavated area of NB-8 two major rock types were mapped i.e. grayish-white quartzitic sandstones and purplish-gray quartzitic sandstones. In grayish-white quartzitic sandstones, quartz content is $98 \%$ including crystalline siliceous matrix, chlorite and calcite contents $2 \%$ with accessory cryptocrystalline silica, zircon and apatite and all minerals are very fresh. In purplish-gray quartzitic sandstones, quartz content is varying between $86 \%$ and $89 \%$, chlorite contents $1 \%$, iron oxide varying between $10 \%$ to $13 \%$ mainly as matrix with accessory zircon and apatite and all minerals are very fresh. Glauconite coating/layer (up to $1 \mathrm{~cm}$ ) was recorded along the bedding planes of grayish-white quartzitic sandstones and purplish-gray quartzitic sandstones. Glauconite is an iron potassium phyllosilicate mineral of characteristic green colour with very low weathering resistance and very friable. Its specific gravity ranges from 2.4 to 2.95. The NB-8 area is characterized by joints (bedding and vertical) and fractures. Ripple marks were also mapped in grayish-white quartzitic sandstones of RAB-8 foundation level. No other major structure, other than joints, shears and ripple marks, was recorded in this area. The general description of lithology, mapped at the foundation levels and walls of NB-8 is given in Table 3.

The nearest major lineament i.e. Ajmer-Sandia lineament, which is confirmed to be a fault is at $37 \mathrm{~km}$ to the north-east of the site. However, its activity is not established [8]. The other lineaments in this area are very small, generally not exceeding $30 \mathrm{~km}$. Lineament study within $5 \mathrm{~km}$ radius of the RAPP$7 \& 8$ site using the satellite imagery on 1:25,000 scale followed by field check confirmed that there are joints and fractures which control the drainage in the area and there are no active faults [6]. The lineaments are trending mostly in NE-SW, NW-SE and WNW-ESE directions. Atomic Mineral Division has also prepared the lineament map based on the gravity anomaly map of 5 mgal available from the joint work of GSI and NGRI and confirmed no fault within $5 \mathrm{~km}$ radius of RAPP-7\&8 [8]. These studies confirmed that there are no faults within $5 \mathrm{~km}$ radius which meets the Atomic Energy Regulatory Board (AERB) guide SG/S-11 requirement on active fault as well as a long fault which can have a structural relationship with an active fault outside the $5 \mathrm{~km}$ radius. The site falls in zone-II as per seismic zoning map of India [9], and corresponds to an earthquake intensity of VI or less, as per modified Mercalli Intensity Scale.

Table 3. Description of lithology mapped at the foundation levels and walls of NB-8

\begin{tabular}{|c|c|c|c|c|}
\hline $\begin{array}{l}\text { Super } \\
\text { Group }\end{array}$ & Group & Lithology & Mineral Assemblage & Type locality \\
\hline \multirow{2}{*}{$\begin{array}{l}\text { Upper } \\
\text { Vindhyan }\end{array}$} & \multirow{2}{*}{$\begin{array}{l}\text { Kaimur Group } \\
\text { Proterozoic age } \\
(940 \pm 40 \\
\text { million years })\end{array}$} & $\begin{array}{l}\text { Grayish-white } \\
\text { quartzitic } \\
\text { sandstones }\end{array}$ & $\begin{array}{l}\text { Quartz content is } 98 \% \text { including } \\
\text { crystalline siliceous matrix, chlorite } \\
\text { and calcite contents } 2 \% \text { with } \\
\text { accessory cryptocrystalline silica, } \\
\text { zircon and apatite and all minerals } \\
\text { are very fresh }\end{array}$ & $\begin{array}{l}\text { Vertical walls of RAB-8, } \\
\text { foundation level of RAB-8, } \\
\text { inclined walls of RB- } 8 \text { and } \\
\text { ECCS south pit. }\end{array}$ \\
\hline & & $\begin{array}{l}\text { Purplish-gray } \\
\text { quartzitic } \\
\text { sandstones }\end{array}$ & $\begin{array}{l}\text { Quartz content is } 86 \% \text { to } 89 \% \text {, } \\
\text { chlorite contents } 1 \% \text {, iron oxide } \\
10 \% \text { to } 13 \% \text { with accessory zircon } \\
\text { and apatite and all minerals are } \\
\text { very fresh }\end{array}$ & $\begin{array}{l}\text { Foundation level of RAB- } \\
8, \text { RB- } 8 \& \text { ECCS Pits, } \\
\text { inclined walls of RB- } 8 \text { and } \\
\text { ECCS pits and vertical } \\
\text { walls of RAB- } 8\end{array}$ \\
\hline
\end{tabular}

\section{Engineering Geological and Geotechnical Assessment of Foundation}

\subsection{Geological Mapping}

Foundation floor engineering geological mapping is essential for important civil structures to provide permanent data set for geological interpretations. For very important structure like nuclear building, the supporting foundation strata should be studied and documented to provide data for credible geologic interpretations [10]. Shallow foundations cover such types of foundations in which load transfer is through direct bearing pressure of the bearing strata. Rock is recognized as the best foundation material. However, design engineers should be aware of the dangers associated with heterogeneity and 
unfavourable rock conditions since over stressing a rock foundation may result in large differential settlements or perhaps sudden failures.

Geological mapping of floor areas was done after the design foundation excavation levels and before first pour of concrete. The sites were excavated up to the foundation levels only, because rocks were fresh and very competent. Reactor Building (RB-8) will be resting on a raft of $7.7 \mathrm{~m}$ thick at about 8.5 $\mathrm{m}$ below the existing ground level for functional requirement in which various rooms and water storage galleries are present. RAB- 8 will be resting on a raft of $3.5 \mathrm{~m}$ thick at about $10.2 \mathrm{~m}$ below the existing ground level for functional requirement. For RB-8 reduced level of finished foundation floor level is +83.800 m corresponding to elevation level (EL) +392.100 m. For RAB-8 reduced level of finished floor level is $+86.300 \mathrm{~m}$ corresponding to elevation level (EL) $+394.600 \mathrm{~m}$. The reduced level of finished floor of ECCS south and north pits is $+81.800 \mathrm{~m}$ corresponding to elevation level (EL) $+390.100 \mathrm{~m}$. The total excavated area i.e. $8583.914 \mathrm{~m}^{2}$ of RB-8, RAB-8, ECCS-S and ECCS-N foundations was mapped. Based on the field observations and evidences, it was found that entire floor areas of RB-8, RAB- 8 , ECCS-S and ECCS-N pits consist of fine to medium grained, compact grayish-white and purplish-gray quartzitic sandstones (Fig. 2). Glauconite layers are present all along the bedding planes. The floor region of this RB- 8 and RAB-8 raft foundations was seen to contain certain iron stained and weathered zone along major vertical joints. The entire floor area of ECCS-N pit was made up of compact and sound rock mass. No evidence of faulting was observed on the surface of floor areas. However, there were some isolated patches of soft and weathered/altered rock. The structural features observed during the mapping exercise indicated the need for consolidation grouting so that the entire floor areas function as single rock mass.

The rock mass of the floor areas was classified as fresh rock as per the weathering grade (W-I). In the northern portion of the RB-8 floor, vertical joint trending in $\mathrm{N}_{2} 60^{\circ}$ direction, with a strike length of more than $45 \mathrm{~m}$ was mapped (feature MVj-A in Fig. 2). In the western portion of the RAB-8 floor, set of discontinuous vertical joints trending between $\mathrm{N} 250^{\circ}$ and $\mathrm{N} 260^{\circ}$ direction with a strike length of more than $7.5 \mathrm{~m}$ were mapped (feature $\mathrm{Vj}$ in Fig. 2). In the northeastern portion of the RAB-8 floor, set of discontinuous vertical joints trending in $\mathrm{N} 260^{\circ}-275^{\circ}$ direction, with a strike length of more than $9.5 \mathrm{~m}$ were also mapped (feature $\mathrm{Vj}$ in Fig. 2). These major joints had shown the maximum weathering effects within $1 \mathrm{~m}$, which is characterized by closely spaced fractures and slightly weathered (W-II) nature. These joints were intersected by vertical minor (up to $1 \mathrm{~m}$ ) joint set at an acute angle at some portions. Because of the presence of these criss-cross joints in some portion, the floor areas were disintegrated. Filling up to $5 \mathrm{~cm}$ of rock fragments was recorded along these vertical joints. No displacement was observed along these features. Along these vertical joints the rock mass was relatively weak, moderately fractured in the isolated patches and no shearing effects were observed on the surface. Joint was tight and crushed rock masses were also well cemented. No cavity or soft material was observed along these joints. Iron staining up to $1.5 \mathrm{~m}$ was recorded along these vertical joints. Special care should be taken to consolidate the rock mass along these joints. No vertical joint was present in the ECCS-S and ECCS-N pits floor or wall areas.

Ripple marks, produced by the water action at the time of formation of these rocks, were also mapped at the foundation level of RAB-8. In the eastern and north-eastern part of RAB-8 foundation area, fractured rock mass zones were mapped. They are confined to two layers i.e. from 10 to $67 \mathrm{~cm}$. Apart from the above mentioned structural features, scattered presence of small to large $(1-15 \mathrm{~m})$ and shallow fracture and cracks due to blasting/excavation was observed in the floor areas. These cracks are generally tight but opening up to $2 \mathrm{~mm}$ were also reported.

The total excavated area i.e. $1213.242 \mathrm{~m}^{2}$ of RB-8, ECCS-S and ECCS-N inclined walls were also mapped. The inclined wall areas of RB-8 and ECCS-S pit consist of fine to medium grained, compact grayish-white quartzitic sandstone and purplish-gray sandstones while the ECCS-N pit walls consist of fine to medium grained, fresh purplish-gray quartzitic sandstone. On the walls, which are inclined at $45^{\circ}$, most prominent joint sets are the bedding joints and on the basis of their joint characteristics horizontal/bedding joints are categorized into three classes i.e. horizontal sheared open master bedding joints (HSMBJ); horizontal tight master bedding joints (HTMBJ) and traces of bedding joints. Infilling of crushed rock fragments up to $10 \mathrm{~cm}$ was recorded along HSMBJ. All the horizontal joints are dipping at $2^{\circ}$ to $6^{\circ}$ towards WSW. The strike length of HSMBJ and HTMBJ are more than $100 \mathrm{~m}$ while the strike length of traces of bedding planes was varying between $5 \mathrm{~m}$ and $15 \mathrm{~m}$. The major vertical joint (feature A in Fig. 2) discussed above for the RB-8 floor area was also intersecting the western inclined 
wall of RB-8. In the ECCS-S pit inclined wall, along the bedding joints glauconite coating/layer was recorded and the thickness of this layer was varying from $2 \mathrm{~mm}$ to $1 \mathrm{~cm}$. Along all the vertical joint, present in the inclined wall, staining affect was recorded.

\subsection{Laboratory Testing and Geotechnical Assessment}

Selected rock core samples from the boreholes drilled in the NB-8 area were tested for physicomechanical properties of rocks in the laboratory of Sohams Foundation Engineering Pvt. Ltd. The intact rock properties at the foundation levels given in table 4 were evaluated considering the necessity in the overall context of the design requirements of the foundations. The values for the dry density of quartzitic sandstone are 2.45 to $2.60 \mathrm{~g} / \mathrm{cc}$ belonging to moderate to high density category. The water absorption values are quite low. Uniaxial compressive strength and deformability characteristic i.e. Modulus of Elasticity and Poisson's ratio were determined. According to strength classification criterion for rock substance [3], the rocks are of very high strength. The Modulus of Elasticity values are ranges from 27.65 GPa to $42.84 \mathrm{GPa}$ and fall under very good rock mass category. Poisson's ratio is 0.30 which is high. Quartzitic sandstone shows higher cohesion. Friction angle is varying from $65^{\circ}$ to $75^{\circ}$ possibly due to variation in roughness of the fractured surface.

The rock mass properties at the foundation levels, combining geological data, drilling data and geophysical are given in Table 5. Field permeability tests (double packer tests) were carried out in all boreholes over the entire depth, in $3 \mathrm{~m}$ sections starting from the bottom of the hole up to the top of borehole. Construction of packer was critically done so as to ensure no leakage. Lugeon values are ranging from 0.06 to 0.09 , falling under very low classification category and indicating that conditions of rock mass discontinuities are very tight.

Table 4. Physico-mechnical properties of intact rock at foundation levels of NB-8 structures

\begin{tabular}{|c|c|c|c|c|c|c|c|c|}
\hline \multirow[t]{2}{*}{ Rock Type } & \multirow{2}{*}{$\begin{array}{l}\text { Dry } \\
\text { Density } \\
(\mathrm{g} / \mathrm{cc})\end{array}$} & \multirow{2}{*}{$\begin{array}{l}\text { Water } \\
\text { Absorption } \\
(\%)\end{array}$} & \multirow{2}{*}{$\begin{array}{l}\text { Specific } \\
\text { Gravity } \\
(\mathrm{g} / \mathrm{cc})\end{array}$} & \multirow{2}{*}{$\begin{array}{l}\text { Uniaxial } \\
\text { Compressive } \\
\text { Strength } \\
(\mathrm{MPa})\end{array}$} & \multirow{2}{*}{$\begin{array}{l}\text { Modulus } \\
\text { of } \\
\text { Elasticity } \\
(\mathrm{GPa})\end{array}$} & \multirow[t]{2}{*}{$\begin{array}{l}\text { Poisson's } \\
\text { Ratio }\end{array}$} & \multicolumn{2}{|c|}{$\begin{array}{l}\text { Shear Strength } \\
\text { Parameter }\end{array}$} \\
\hline & & & & & & & $\begin{array}{l}\mathrm{C} \\
(\mathrm{MPa})\end{array}$ & $\begin{array}{l}\text { Friction } \\
\text { Angle } \\
\text { (Degree) }\end{array}$ \\
\hline $\begin{array}{l}\text { Quartizitic } \\
\text { Sandstones }\end{array}$ & $\begin{array}{l}2.45^{-} \\
2.60\end{array}$ & $0.24-2.15$ & $\begin{array}{l}2.59- \\
2.98\end{array}$ & $103.20-116.60$ & $\begin{array}{l}27.65^{-} \\
42.84\end{array}$ & 0.30 & $\begin{array}{l}0.95_{-}^{-} \\
3.10\end{array}$ & $65-75$ \\
\hline
\end{tabular}

Table 5. Properties of rock mass at the foundation levels of NB-8 structures

\begin{tabular}{|c|c|c|c|c|c|c|c|c|c|c|}
\hline \multirow[t]{2}{*}{ Rock Type } & \multirow{2}{*}{$\begin{array}{l}\text { Major } \\
\text { Joints }\end{array}$} & \multirow{2}{*}{$\begin{array}{l}\text { Weathering } \\
\text { Grade }\end{array}$} & \multirow{2}{*}{$\begin{array}{l}\text { Core } \\
\text { Recovery } \\
(\%)\end{array}$} & \multirow{2}{*}{$\begin{array}{l}\text { RQD } \\
(\%)\end{array}$} & \multirow{2}{*}{$\begin{array}{l}\mathrm{Vp} \\
(\mathrm{km} / \mathrm{sec})\end{array}$} & \multirow{2}{*}{$\begin{array}{l}\text { Water } \\
\text { Level } \\
(\mathrm{m})\end{array}$} & \multirow{2}{*}{$\begin{array}{l}\text { Permeability } \\
\text { (lugeon) }\end{array}$} & \multicolumn{2}{|l|}{ RMR } & \multirow{2}{*}{$\begin{array}{l}\text { Level of } \\
\text { Acceptable } \\
\text { Foundation } \\
\text { (m) }\end{array}$} \\
\hline & & & & & & & & $\begin{array}{l}\text { Values } \\
\text { (Range) }\end{array}$ & Class & \\
\hline \multirow[t]{3}{*}{$\begin{array}{l}\text { Quartizitic } \\
\text { Sandstones }\end{array}$} & \multirow{3}{*}{$\begin{array}{l}\text { MVj, } \\
\text { HSMBJ, } \\
\text { HTMBJ }\end{array}$} & \multirow[t]{3}{*}{ W-I to W-II } & \multirow[t]{3}{*}{100} & \multirow[t]{3}{*}{$\begin{array}{l}75- \\
100\end{array}$} & \multirow[t]{3}{*}{$3.85-4.40$} & \multirow[t]{3}{*}{$\begin{array}{l}17.50- \\
31.1\end{array}$} & \multirow[t]{3}{*}{$0.06-0.09$} & \multirow[t]{3}{*}{$65-75$} & \multirow[t]{3}{*}{$\begin{array}{l}\text { Good } \\
\text { Rock }\end{array}$} & $\begin{array}{l}\mathrm{El}+392.100 \mathrm{~m} \\
\text { for RB-8 }\end{array}$ \\
\hline & & & & & & & & & & $\begin{array}{l}\mathrm{El}+394.600 \mathrm{~m} \\
\text { for RAB-8 }\end{array}$ \\
\hline & & & & & & & & & & $\begin{array}{l}\mathrm{El}+390.100 \mathrm{~m} \\
\text { for ECCS-S \& } \\
\mathrm{N} \text { pits }\end{array}$ \\
\hline
\end{tabular}




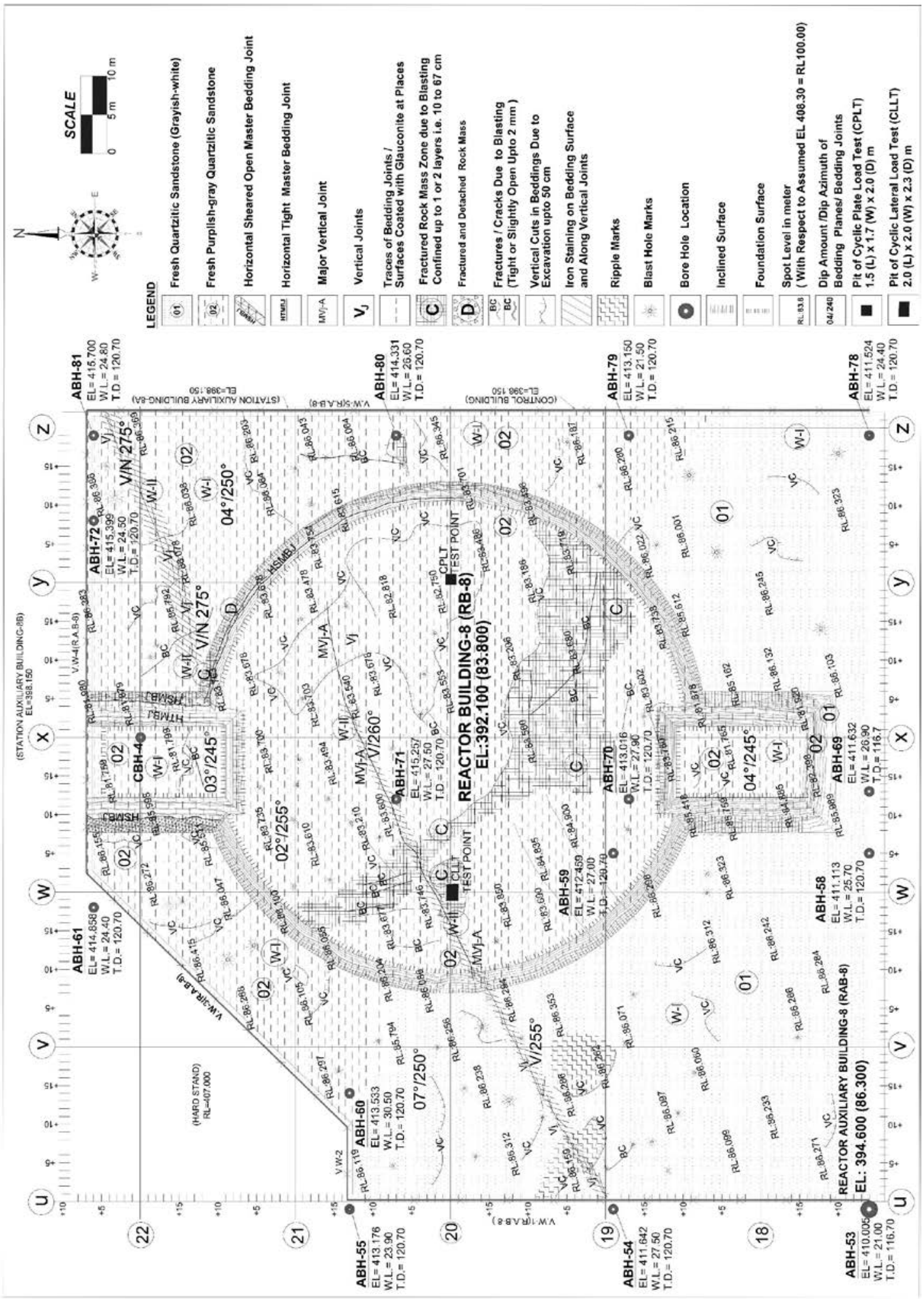

Figure 2. Geological plan map of nuclear building-8 of RAPP unit 8 


\section{$5 \quad$ Observations and Conclusions}

Based on the field observations and evidences, it was concluded that area in the floors and inclined walls of RB- 8 and ECCS-S pit and floor of RAB- 8 is characterized by grayish-white quartzitic sandstone (containing quartz including crystalline siliceous matrix, chlorite and calcite) and purplish-gray quartzitic sandstone (containing Quartz, chlorite and iron oxide) while the floor and inclined walls of ECCS-N pit werecharacterized by purplish-gray quartzitic sandstones. Depth persistence and lateral prevalence of bed rock were established. In general, the floors were falling in W-I weathering grade, indicating fresh rock mass conditions and drilling data confirming the same below the foundation levels. The grade of the rock mass as evaluated from the drill cores, core recoveries, RQD and condition of discontinuities, indicate that RMR vary from 65 to 75 and fall under good rock mass. Consolidation grouting up to $9 \mathrm{~m}$ depth in the foundation of RB- 8 using primary and secondary holes was recommended, which was decided based on the structural features observed during the mapping, so that the entire floor area functions as monolithic or single rock mass. $6 \mathrm{~m}$ spacing for the primary and $3 \mathrm{~m}$ for secondary holes was recommended. Special care should be taken to consolidate rock mass along the weak zone of master joints (feature MVj-A in Fig. 2). With the present geological mapping and detailed on-site and laboratory investigations, the foundation is suitable to locate a nuclear power plant, meeting all the safety norms, as prescribed by national and regulatory standards.

Acknowledgements: The authors would like to thank Nuclear Power Corporation of India Limited for permitting to send this paper for publication. The present work is a part of the sponsored project by Hindustan Construction Company (HCC), thus, the authors thank the Management of HCC for the same. We sincerely thank Director NIRM for providing technical guidance and valuable advice during the preparation of this manuscript.

\section{References}

1. A. K. Naithani, Prasnna Jain, Rabi Bhusan, J. K. Jain and P. C. Nawani, "Geological mapping of foundation floor for Nuclear Building of Rajasthan Atomic Power Project, Rawatbhata, India," Special Publication of the Geological Society of India No. 4, pp 111-118, 2016.

2. EM 1110-1-1804, "Engineering and design- geotechnical investigations, Appendix B Geologic mapping procedures open excavations," Department of the Army US Army Corps of Engineers Washington, DC B-1 to B-19, 2001.

3. ISRM, "Suggested methods for rock characterization, testing and monitoring", Commission on Testing Methods, International Society of Rock Mechanics, (Brown, E.T. ed.), Pergamon Press, 211 p, 1981.

4. Z. T. Bieniawski, "Engineering rock mass classification", John Willey \& Sons, New York, 251 p, 1989.

5. Balmiki Prasad, "Geology, sedimentation and palaeogeography of the Vindhyan Super Group, South-Eastern Rajasthan", Memoir Geological Survey of India, vol. 116, Part-I, 103 p, 1984.

6. S. Prasad, A. Som, A. G. Chhatre, U. P. Singh and F. Dastageer, "Lineament study and their field check within $5 \mathrm{~km}$ radius of RAPP-7 \& 8, Rawatbhata, Chittorgarh, Rajasthan", Nuclear Power Corporation of India Limited Report No. NPCIL/SA\&S/01/01400/M, 12 p, 2010.

7. Y. R. Sathya Saradhi and D. C. Banerjee, "A note on geology and tectonics around $40 \mathrm{~km}$ of Ranapratapsagar site, Rajasthan", Report of Department of Atomic Energy, Atomic Minerals Division, Hyderabad, 5 p, 1989.

8. A. G. Chhatre, "Geological study of RAPP site and site clearance for RAPP-7\&8," Nuclear Power Corporation of India Limited Report No. NPCIL/SA\&S//01900/M, 37 p, 2010.

9. IS 1893, "Criteria for earthquake resistant design of structures, Part 1 - general provisions and buildings", Bureau of Indian Standards, New Delhi, 36 p, 2002.

10. C. Harikumar, C. S. Pillai and S. C. Chetal, "Foundation floor geological mapping of a nuclear reactor," Geotechnical and Geological Engineering, vol. 28, pp 503-511, 2010. 